\title{
URINARY HEMOGLOBIN EXCRETION AND RENAL CIRCULATORY DYNAMICS : A STUDY OF THE EFFECT OF L-NOREPINEPHRINE IN THE DOG ${ }^{1,2}$
}

\author{
By WILLOUGHBY LATHEM 3 AND ALVIN D. BENJAMIN 4 \\ (From the Department of Internal Medicine, Yale University School of Medicine, and the \\ Veterans Administration Hospital, West Haven, Conn.)
}

(Submitted for publication June 13, 1956; accepted October 4, 1956)

The passage of protein molecules across capillary walls is governed by the characteristics of the molecule and the membrane and appears to occur by a process of both filtration and diffusion. From a study of these processes within the isolated, perfused hind limb of the cat $(2,3)$ and from mathematical considerations and other studies $(2,4)$ it has been suggested that the transcapillary transport of protein and the degree of molecular sieving of protein molecules across membranes during ultrafiltration may be influenced by concentration gradients of protein between filtrate and filtrand and by the rate of filtration of water through the capillary wall. Moreover, it has been suggested that these processes may be influenced by factors which modify the level of hydrostatic pressure within the capillary $(2,5,6)$.

Within the kidney these processes have not been subjected to extensive study. That intraglomerular hydrostatic pressure may modify the rate of filtration of protein molecules has been suggested by experiments in which renin, which presumably elevates intraglomerular pressure, has been shown to accelerate the urinary excretion of plasma proteins $(7,8)$ and hemoglobin $(9)$. A change in pressure has also been invoked to account, at least in part, for the augmentation of protein clearances following the administration of serum albumin intravenously to patients with renal disease (5).

\footnotetext{
1 Supported by grants from the National Heart Institute, United States Public Health Service, and the American Heart Association and Greenwich Health Association.

2 The results of this study have been published in abstract form (1).

${ }^{3}$ Present address : Department of Medicine, University of Pittsburgh School of Medicine, Pittsburgh, Pennsylvania.

4 This work was submitted to the Faculty of Medicine, Yale University, in partial fulfillment of requirements for the degree of Doctor of Medicine.
}

Of molecular sieving within the kidney and of the influence of changes in glomerular filtration rate, little is known.

In the present investigation these factors were examined in normal, anesthetized dogs. The rate of urinary excretion and renal clearance of hemoglobin were studied under conditions in which renal hemodynamics and glomerular filtration rate were modified by infusions of the adrenal medullary hormone, 1-norepinephrine.

\section{METHOD}

A study of the effects of 1-norepinephrine was made in 20 female mongrel dogs weighing 7 to $20 \mathrm{~kg}$. All animals were deprived of food, but not water, for 24 hours prior to the test. Anesthesia was induced with sodium pentobarbital, $30 \mathrm{mgm}$. per $\mathrm{kg}$. intravenously, and was maintained by the administration of $100 \mathrm{mgm}$. of this drug at intervals throughout the study. An indwelling needle was placed in a femoral artery. Priming and sustaining infusions of creatinine and p-aminohippurate were administered intravenously for measurement of glomerular filtration rate and renal plasma flow, respectively. Along with these substances, solutions of dog hemoglobin were administered intravenously in amounts sufficient to maintain a relatively constant arterial plasma level of hemoglobin of from 212 to $504 \mathrm{mgm}$. per cent, values well above the renal threshold (10). Priming doses consisted of from one to two grams of hemoglobin in $50 \mathrm{ml}$. of 5 per cent dextrose and distilled water. The sustaining infusion contained hemoglobin in a concentration of from 430 to $760 \mathrm{mgm}$. per cent and was made up in 5 per cent dextrose and distilled water. This was administered at a constant rate of from 1 to $2 \mathrm{mgm}$. of hemoglobin per minute.

After allowing 30 minutes for equilibration of these substances, the urine, collected by urethral catheter, was discarded and the bladder was washed out with distilled water and emptied by manual compression after the introduction of air to facilitate emptying. Three consecutive 10 to 20 -minute control clearance periods were then obtained. Following this an infusion of 1-norepinephrine (16 $\mu \mathrm{g}$. per $\mathrm{ml}$.) was administered intravenously at a rate sufficient to elevate mean arterial blood pressure, measured with a mercury manometer, 20 to $50 \mathrm{~mm}$. $\mathrm{Hg}$. This 
TABLE I

Urinary hemoglobin excretion and renal hemodynamics during the infusion of Lnorepinephrine*

\begin{tabular}{|c|c|c|c|c|c|c|c|c|c|c|c|}
\hline $\begin{array}{l}\text { Dog } \\
\text { No. }\end{array}$ & $\begin{array}{l}\text { Wt. } \\
\mathbf{K g} .\end{array}$ & Procedure & $\underset{m m . P}{\text { B.P. }} \boldsymbol{g}$ & $\underset{\min }{\mathrm{HR}}$ & $\underset{m l . / m i n .}{\text { GFR }}$ & $\underset{m l . / m i n}{\mathrm{RPF}}$ & $\mathbf{F F}$ & $\underset{m g m . \%}{\mathrm{PH}_{\mathbf{g b}}}$ & $\underset{m g m . / m i n}{\mathrm{UH}_{\mathrm{g}} \mathrm{V}}$ & $\underset{m l . / m i n .}{C_{H z b}}$ & $\frac{\frac{\mathrm{C}_{\mathrm{H}_{\mathrm{gb}}}}{\mathrm{C}_{\mathrm{or}}}}{\mathrm{\%}_{\mathrm{o}}}$ \\
\hline 3 & 10 & $\begin{array}{l}\text { Control } \\
\text { Infusion }\end{array}$ & $\begin{array}{l}114 \\
165\end{array}$ & $\begin{array}{r}120 \\
72\end{array}$ & $\begin{array}{l}54 \\
41\end{array}$ & $\begin{array}{r}112 \\
76\end{array}$ & $\begin{array}{l}.482 \\
.541\end{array}$ & $\begin{array}{l}250 \\
305\end{array}$ & $\begin{array}{l}3.04 \\
4.22\end{array}$ & $\begin{array}{l}1.22 \\
1.38\end{array}$ & $\begin{array}{l}2.28 \\
3.42\end{array}$ \\
\hline 7 & 17 & $\begin{array}{l}\text { Control } \\
\text { Infusion }\end{array}$ & $\begin{array}{r}94 \\
140\end{array}$ & $\begin{array}{l}140 \\
180\end{array}$ & $\begin{array}{l}35 \\
21\end{array}$ & $\begin{array}{l}70 \\
34\end{array}$ & $\begin{array}{l}.501 \\
.620\end{array}$ & $\begin{array}{l}249 \\
348\end{array}$ & $\begin{array}{l}2.30 \\
4.22\end{array}$ & $\begin{array}{l}0.92 \\
1.12\end{array}$ & $\begin{array}{l}2.65 \\
5.71\end{array}$ \\
\hline 8 & 20 & $\begin{array}{l}\text { Control } \\
\text { Infusion }\end{array}$ & $\begin{array}{l}104 \\
140\end{array}$ & $\begin{array}{l}120 \\
120\end{array}$ & $\begin{array}{l}98 \\
85\end{array}$ & $\begin{array}{l}207 \\
147\end{array}$ & $\begin{array}{l}.471 \\
.587\end{array}$ & $\begin{array}{l}212 \\
223\end{array}$ & $\begin{array}{l}2.11 \\
4.18\end{array}$ & $\begin{array}{l}0.93 \\
1.87\end{array}$ & $\begin{array}{l}0.99 \\
2.18\end{array}$ \\
\hline 9 & 7 & $\begin{array}{l}\text { Control } \\
\text { Infusion }\end{array}$ & $\begin{array}{r}85 \\
115\end{array}$ & $\begin{array}{l}160 \\
140\end{array}$ & $\begin{array}{l}48 \\
20\end{array}$ & $\begin{array}{l}87 \\
43\end{array}$ & $\begin{array}{l}.552 \\
.473\end{array}$ & $\begin{array}{l}504 \\
501\end{array}$ & $\begin{array}{l}4.58 \\
3.71\end{array}$ & $\begin{array}{l}0.91 \\
0.74\end{array}$ & $\begin{array}{l}2.09 \\
3.71\end{array}$ \\
\hline 10 & 7 & $\begin{array}{l}\text { Control } \\
\text { Infusion }\end{array}$ & $\begin{array}{l}110 \\
135\end{array}$ & $\begin{array}{l}160 \\
128\end{array}$ & $\begin{array}{l}31 \\
39\end{array}$ & $\begin{array}{l}135 \\
118\end{array}$ & $\begin{array}{l}.230 \\
.350\end{array}$ & $\begin{array}{l}394 \\
470\end{array}$ & $\begin{array}{l}0.72 \\
2.28\end{array}$ & $\begin{array}{l}0.18 \\
0.48\end{array}$ & $\begin{array}{l}0.61 \\
1.26\end{array}$ \\
\hline 11 & 8 & $\begin{array}{l}\text { Control } \\
\text { Infusion }\end{array}$ & $\begin{array}{r}85 \\
130\end{array}$ & $\begin{array}{l}130 \\
100\end{array}$ & $\begin{array}{r}27 \\
8\end{array}$ & $\begin{array}{r}131 \\
23\end{array}$ & $\begin{array}{l}.203 \\
.427\end{array}$ & $\begin{array}{l}354 \\
403\end{array}$ & $\begin{array}{l}1.90 \\
1.71\end{array}$ & $\begin{array}{l}0.54 \\
0.43\end{array}$ & $\begin{array}{l}2.04 \\
5.69\end{array}$ \\
\hline 12 & 12 & $\begin{array}{l}\text { Control } \\
\text { Infusion }\end{array}$ & $\begin{array}{r}95 \\
130\end{array}$ & $\begin{array}{l}140 \\
128\end{array}$ & $\begin{array}{l}31 \\
26\end{array}$ & $\begin{array}{l}92 \\
82\end{array}$ & $\begin{array}{l}.339 \\
.316\end{array}$ & $\begin{array}{l}317 \\
379\end{array}$ & $\begin{array}{l}2.18 \\
4.40\end{array}$ & $\begin{array}{l}0.68 \\
1.16\end{array}$ & $\begin{array}{l}2.20 \\
4.46\end{array}$ \\
\hline 13 & 13 & $\begin{array}{l}\text { Control } \\
\text { Infusion }\end{array}$ & $\begin{array}{l}120 \\
150\end{array}$ & $\underline{132}$ & $\begin{array}{l}32 \\
17\end{array}$ & $\begin{array}{r}117 \\
50\end{array}$ & $\begin{array}{l}.276 \\
.355\end{array}$ & $\begin{array}{l}308 \\
391\end{array}$ & $\begin{array}{l}2.35 \\
6.97\end{array}$ & $\begin{array}{l}0.77 \\
1.79\end{array}$ & $\begin{array}{r}2.44 \\
10.36\end{array}$ \\
\hline 14 & 9 & $\begin{array}{l}\text { Control } \\
\text { Infusion }\end{array}$ & $\begin{array}{l}100 \\
130\end{array}$ & $\begin{array}{l}132 \\
168\end{array}$ & $\begin{array}{l}24 \\
13\end{array}$ & $\begin{array}{l}76 \\
36\end{array}$ & $\begin{array}{l}.320 \\
.428\end{array}$ & $\begin{array}{l}336 \\
397\end{array}$ & $\begin{array}{l}2.66 \\
3.47\end{array}$ & $\begin{array}{l}0.89 \\
0.91\end{array}$ & $\begin{array}{l}3.83 \\
8.22\end{array}$ \\
\hline 15 & 7 & $\begin{array}{l}\text { Control } \\
\text { Infusion }\end{array}$ & $\begin{array}{r}90 \\
110\end{array}$ & $\begin{array}{l}124 \\
160\end{array}$ & $\begin{array}{l}23 \\
15\end{array}$ & $\begin{array}{l}53 \\
33\end{array}$ & $\begin{array}{l}.435 \\
.466\end{array}$ & $\begin{array}{l}395 \\
410\end{array}$ & $\begin{array}{l}3.12 \\
4.30\end{array}$ & $\begin{array}{l}0.88 \\
1.06\end{array}$ & $\begin{array}{l}3.90 \\
7.68\end{array}$ \\
\hline 16 & 15 & $\begin{array}{l}\text { Control } \\
\text { Infusion }\end{array}$ & $\begin{array}{r}90 \\
120\end{array}$ & $\begin{array}{l}156 \\
160\end{array}$ & $\begin{array}{l}44 \\
38\end{array}$ & $\begin{array}{r}111 \\
91\end{array}$ & $\begin{array}{l}.406 \\
.415\end{array}$ & $\begin{array}{l}244 \\
283\end{array}$ & $\begin{array}{l}2.71 \\
3.28\end{array}$ & $\begin{array}{l}1.12 \\
1.16\end{array}$ & $\begin{array}{l}2.56 \\
3.70\end{array}$ \\
\hline 19 & 13 & $\begin{array}{l}\text { Control } \\
\text { Infusion }\end{array}$ & $\begin{array}{l}105 \\
135\end{array}$ & $\begin{array}{l}132 \\
120\end{array}$ & $\begin{array}{l}23 \\
12\end{array}$ & $\begin{array}{l}56 \\
30\end{array}$ & $\begin{array}{l}.434 \\
.397\end{array}$ & $\begin{array}{l}244 \\
310\end{array}$ & $\begin{array}{l}3.62 \\
3.16\end{array}$ & $\begin{array}{l}1.50 \\
1.03\end{array}$ & $\begin{array}{l}6.54 \\
8.83\end{array}$ \\
\hline 31 & 16 & $\begin{array}{l}\text { Control } \\
\text { Infusion }\end{array}$ & $\begin{array}{l}100 \\
150\end{array}$ & $\begin{array}{l}112 \\
100\end{array}$ & $\begin{array}{l}98 \\
88\end{array}$ & $\begin{array}{l}209 \\
177\end{array}$ & $\begin{array}{l}.473 \\
.496\end{array}$ & $\begin{array}{l}460 \\
523\end{array}$ & $\begin{array}{l}2.07 \\
3.52\end{array}$ & $\begin{array}{l}0.45 \\
0.68\end{array}$ & $\begin{array}{l}0.47 \\
0.77\end{array}$ \\
\hline 32 & 12 & $\begin{array}{l}\text { Control } \\
\text { Infusion }\end{array}$ & $\begin{array}{l}100 \\
130\end{array}$ & $\begin{array}{r}92 \\
140\end{array}$ & $\begin{array}{l}70 \\
62\end{array}$ & $\begin{array}{r}108 \\
99\end{array}$ & $\begin{array}{l}.648 \\
.630\end{array}$ & $\begin{array}{l}301 \\
405\end{array}$ & $\begin{array}{l}1.69 \\
3.02\end{array}$ & $\begin{array}{l}0.56 \\
0.75\end{array}$ & $\begin{array}{l}0.80 \\
1.21\end{array}$ \\
\hline 17 & 9 & $\begin{array}{l}\text { Control } \\
\text { Infusion } \\
\text { Recovery }\end{array}$ & $\begin{array}{r}98 \\
140 \\
70\end{array}$ & $\begin{array}{l}148 \\
120 \\
134\end{array}$ & $\begin{array}{l}38 \\
27 \\
32\end{array}$ & $\begin{array}{r}106 \\
59 \\
75\end{array}$ & $\begin{array}{l}.358 \\
.470 \\
.422\end{array}$ & $\begin{array}{l}285 \\
321 \\
331\end{array}$ & $\begin{array}{l}1.94 \\
2.40 \\
2.79\end{array}$ & $\begin{array}{l}0.69 \\
0.76 \\
0.85\end{array}$ & $\begin{array}{l}1.81 \\
2.91 \\
2.70\end{array}$ \\
\hline 18 & 9 & $\begin{array}{l}\text { Control } \\
\text { Infusion } \\
\text { Recovery }\end{array}$ & $\begin{array}{r}95 \\
130 \\
90\end{array}$ & $\begin{array}{l}148 \\
120 \\
140\end{array}$ & $\begin{array}{l}37 \\
18 \\
25\end{array}$ & $\begin{array}{r}100 \\
43 \\
63\end{array}$ & $\begin{array}{l}.375 \\
.499 \\
.416\end{array}$ & $\begin{array}{l}273 \\
300 \\
301\end{array}$ & $\begin{array}{l}2.26 \\
2.76 \\
3.19\end{array}$ & $\begin{array}{l}0.83 \\
0.92 \\
1.06\end{array}$ & $\begin{array}{l}2.22 \\
7.59 \\
4.08\end{array}$ \\
\hline 25 & 9 & $\begin{array}{l}\text { Control } \\
\text { Infusion } \\
\text { Recovery }\end{array}$ & $\begin{array}{r}95 \\
140 \\
90\end{array}$ & $\begin{array}{r}100 \\
132 \\
98\end{array}$ & $\begin{array}{l}62 \\
56 \\
57\end{array}$ & $\begin{array}{l}94 \\
90 \\
98\end{array}$ & $\begin{array}{l}.655 \\
.615 \\
.576\end{array}$ & $\begin{array}{l}246 \\
323 \\
331\end{array}$ & $\begin{array}{l}3.96 \\
3.62 \\
5.79\end{array}$ & $\begin{array}{l}1.65 \\
1.12 \\
1.74\end{array}$ & $\begin{array}{l}2.73 \\
2.04 \\
3.02\end{array}$ \\
\hline 33 & 13 & $\begin{array}{l}\text { Control } \\
\text { Infusion } \\
\text { Recovery }\end{array}$ & $\begin{array}{r}110 \\
160 \\
75\end{array}$ & $\begin{array}{l}120 \\
100 \\
138\end{array}$ & $\begin{array}{l}44 \\
32 \\
41\end{array}$ & $\begin{array}{r}117 \\
57 \\
90\end{array}$ & $\begin{array}{l}.396 \\
.555 \\
.459\end{array}$ & $\begin{array}{l}477 \\
598 \\
593\end{array}$ & $\begin{array}{l}2.67 \\
5.50 \\
4.25\end{array}$ & $\begin{array}{l}0.56 \\
0.92 \\
0.71\end{array}$ & $\begin{array}{l}1.28 \\
2.91 \\
1.71\end{array}$ \\
\hline 34 & 10 & $\begin{array}{l}\text { Control } \\
\text { Infusion } \\
\text { Recovery }\end{array}$ & $\begin{array}{r}110 \\
160 \\
75\end{array}$ & $\begin{array}{r}84 \\
136 \\
138\end{array}$ & $\begin{array}{l}69 \\
59 \\
66\end{array}$ & $\begin{array}{r}104 \\
90 \\
142\end{array}$ & $\begin{array}{l}.663 \\
.655 \\
.471\end{array}$ & $\begin{array}{l}345 \\
419 \\
406\end{array}$ & $\begin{array}{l}1.10 \\
2.40 \\
2.01\end{array}$ & $\begin{array}{l}0.32 \\
0.57 \\
0.50\end{array}$ & $\begin{array}{l}0.47 \\
0.98 \\
0.76\end{array}$ \\
\hline 35 & 12 & $\begin{array}{l}\text { Control } \\
\text { Infusion } \\
\text { Recovery }\end{array}$ & $\begin{array}{l}120 \\
160 \\
-\end{array}$ & $\begin{array}{l}144 \\
128 \\
-\end{array}$ & $\begin{array}{l}32 \\
19 \\
19\end{array}$ & $\begin{array}{l}82 \\
35 \\
59\end{array}$ & $\begin{array}{l}.394 \\
.553 \\
.334\end{array}$ & $\begin{array}{l}341 \\
450 \\
441\end{array}$ & $\begin{array}{l}1.25 \\
2.83 \\
1.36\end{array}$ & $\begin{array}{l}0.38 \\
0.63 \\
0.30\end{array}$ & $\begin{array}{l}1.16 \\
3.55 \\
1.74\end{array}$ \\
\hline
\end{tabular}

* All values are averages of three determinations. L-norepinephrine was administered intravenously during infusion periods. Abbreviations are as follows: $B P=$ mean arterial blood pressure; $H R=$ heart rate, beats per minute; $G F R=$ glomerular filtration rate (creatinine clearance); RPF = renal plasma flow (PAH clearance); FF $=$ filtration fraction (GFR/RPF); $P_{\mathrm{H}_{g b}}=$ plasma hemoglobin concentration; $\mathrm{U}_{\mathrm{H}_{\mathrm{gb}} \mathrm{V}}=$ urinary hemoglobin excretion; $\mathrm{C}_{\mathrm{H}_{\mathrm{gb}}}=\mathrm{clearance}_{\mathrm{ef}}$ hemoglobin; $\mathrm{C}_{\mathrm{H}_{\mathrm{gb}}} / \mathrm{C}_{\mathrm{er}}=$ hemoglobin-creatinine clearance ratio. 
required between 4 and $50 \mu \mathrm{g}$. of 1-norepinephrine per minute. In most animals the amount necessary to maintain arterial pressure at the desired level increased progressively throughout the test. After elevation of the arterial pressure for approximately 15 minutes the urine was discarded and three consecutive 10 to 20 -minute clearance periods were obtained during the pressor response to 1-norepinephrine. In each of six animals $(17,18,25,33$, 34 , and 35 ) three recovery periods were obtained immediately following cessation of the infusion of 1-norepinephrine.

Urinary and plasma concentrations of hemoglobin were determined by the method of Evelyn and Malloy (11). Creatinine concentrations in urine and plasma were assayed by the method of Bonsnes and Taussky (12) and PAH levels were determined by the method of Smith, Finkelstein, Aliminosa, Crawford, and Graber (13). Hemoglobin-saline solutions were prepared according to the method of Amberson, Jacobs, Hisey, and Monke (14). Solutions of hemoglobin prepared in this manner were dialyzed against normal saline at $8^{\circ} \mathrm{C}$ for 48 hours. After filtration through a Seitz filter the solution was stored in a sterile container at $8^{\circ} \mathrm{C}$ for periods not exceeding two weeks.

\section{RESULTS}

The results of the effects of 1-norepinephrine on renal hemodynamics and hemoglobin excretion are presented in Table $I$ and in Figures 1 to 6. An illustrative experiment is presented in Figure 1 (dog 33).

\section{Systemic circulatory response}

During the infusion of 1-norepinephrine the arterial blood pressure increased from 20 to $50 \mathrm{~mm}$. $\mathrm{Hg}$, with a mean change of $38 \mathrm{~mm}$. $\mathrm{Hg}$. Considerable variation was encountered in the pressor response to 1-norepinephrine. Some animals required as much as $50 \mu \mathrm{g}$. per minute to maintain the pressure within this range whereas others re-

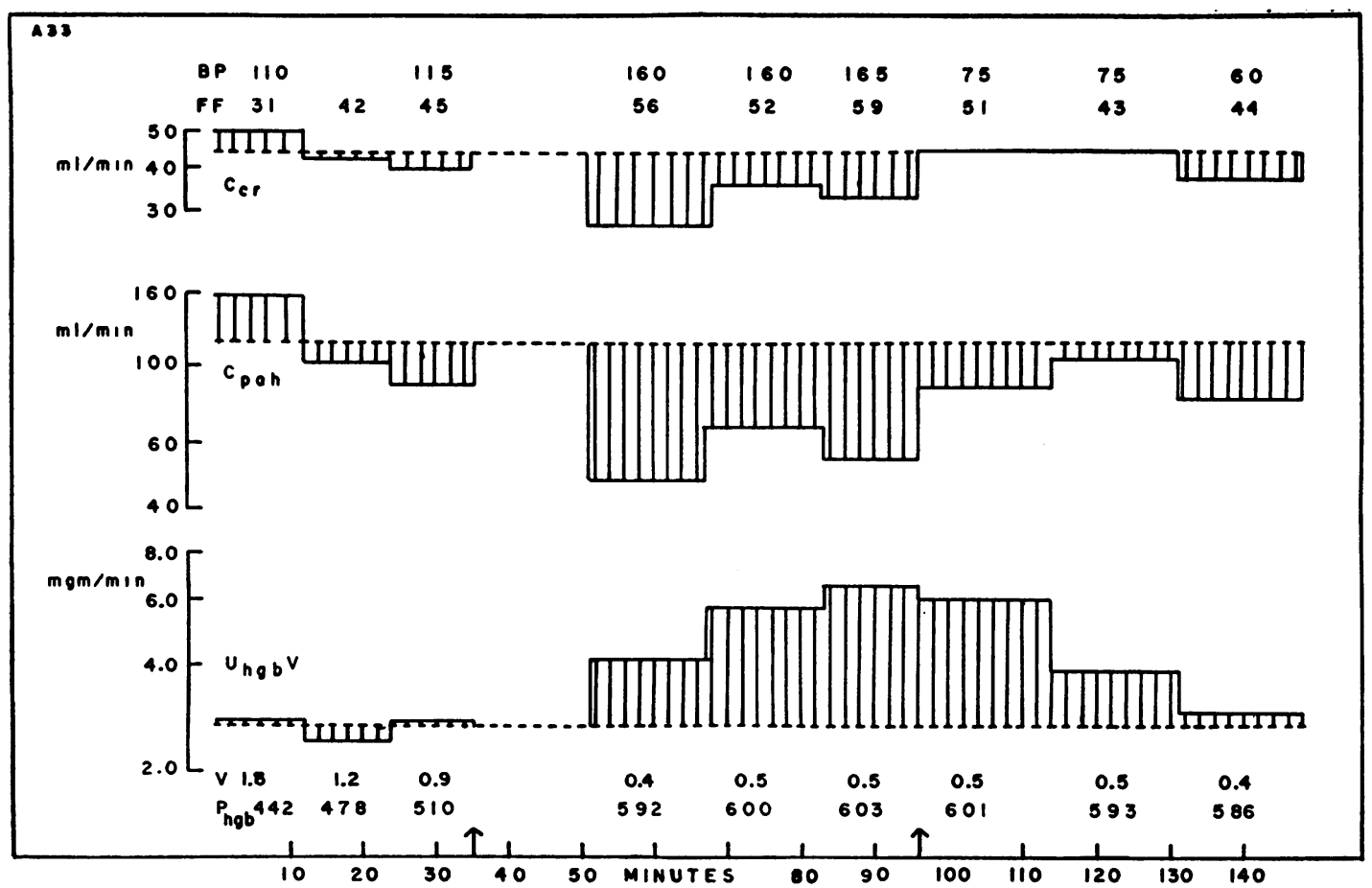

Fig. 1. The Effect of L-Norepinephrine on Renal Function and Urinary Hemoglobin ExCRETION (Dog 33)

Glomerular filtration rate ( $\mathrm{C}_{\mathbf{c}_{r}}$-creatinine clearance), renal plasma flow $\left(\mathrm{C}_{\mathbf{P A B}}\right)$, urinary hemoglobin excretion $\left(U_{H_{g b}} V\right.$ ) and mean arterial blood pressure (BP) were determined before, during and following the administration of 1-norepinephrine. The drug was given intravenously during the time noted between the arrows. The urine obtained during the first 15 minutes after beginning infusion was discarded because of intrarenal delay. Urinary hemoglobin excretion increased in association with a rise in arterial pressure and plasma hemoglobin concentration ( $\mathrm{P}_{\mathbf{H g}}$, at bottom) and a fall in glomerular filtration rate and renal plasma flow. The filtration fraction increased. Urine flow (V) diminished. After the infusion was discontinued all values returned towards control levels. 


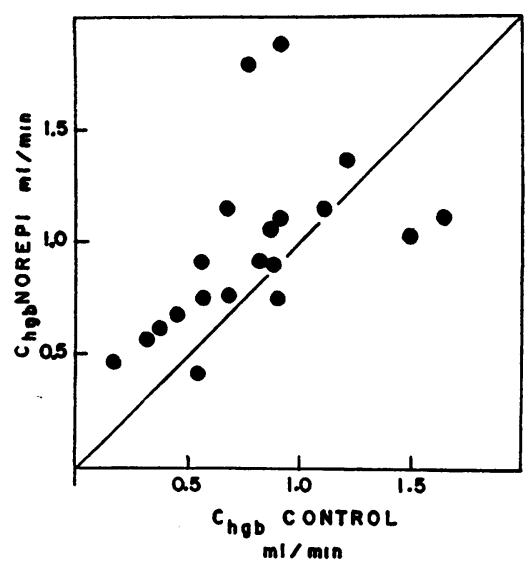

Fig. 2. The Effect of L-Norepinephrine on the Renal Clearance of Hemoglobin

The averaged values for the clearance of hemoglobin during the control periods are plotted against the clearances of this protein during the pressor response to 1-norepinephrine. The clearance of hemoglobin increased in 14 studies, decreased in 4, and remained unchanged in 2 .

quired as little as $4 \mu \mathrm{g}$. per minute. After the infusion was discontinued the blood pressure returned promptly to control levels or below. Two dogs (17 and 33 ) became hypotensive at this time (Table I). In most animals the cardiac rate decreased 20 to 30 beats per minute during infusion of 1-norepinephrine; in others, a tachycardia with

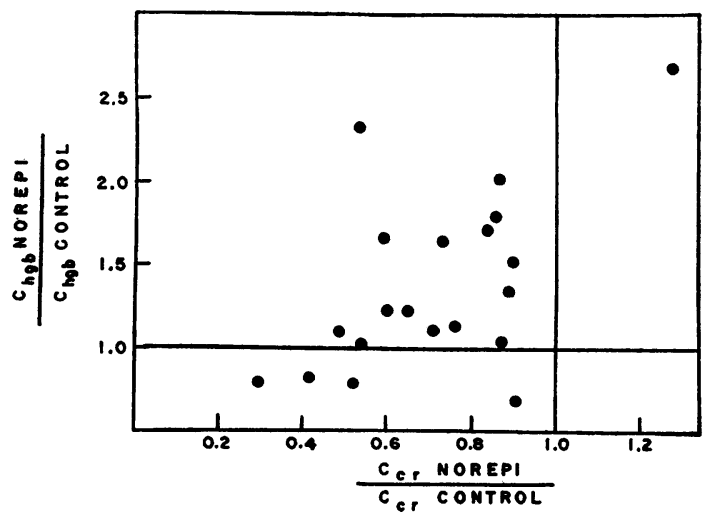

Fig. 3. The Relationship Between the Changes in the Clearance of Hemoglobin and the Clearance of Creatinine During the Pressor Response to L-NOREPINEPHRINE

The ratio of the infusion to the control values of the clearance of hemoglobin is plotted against the changes in the creatinine clearance. The clearance of hemoglobin tended to increase during the infusion of 1-norepinephrine except in those instances when the reduction in the creatinine clearance exceeded 50 per cent of control values. varying degrees of irregularity of cardiac rhythm was observed.

\section{Renal hemodynamics}

During control observations prior to the infusion of 1-norepinephrine the mean renal plasma flow for the entire group of 20 animals was 100 ml. per $10 \mathrm{~kg}$. body weight per minute, a value less than that reported (15) for normal dogs under basal conditions- $135 \mathrm{ml}$. per $10 \mathrm{~kg}$. body weight per minute. The mean renal filtration fraction (GFR/RPF) was 0.43 , a value higher than that reported (15) for normal animals -0.32 . These differences may be attributed to the administration

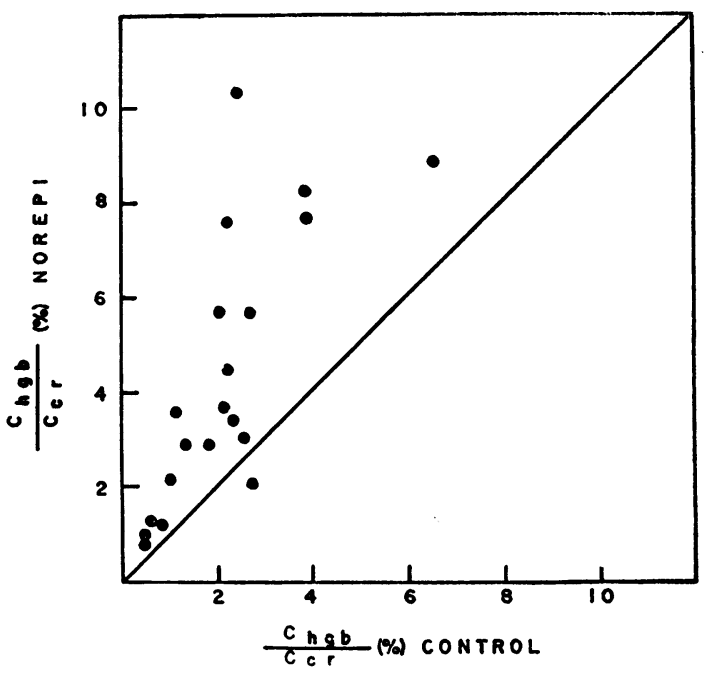

Fig. 4. The Effect of L-Norepinephrine on the Hemoglobin-Creatinine Clearance Ratio

The control values of the hemoglobin-creatinine ratios $\left(\mathrm{C}_{\mathrm{Hgb}} / \mathrm{C}_{\mathrm{Cr}_{\mathrm{r}}}\right)$ are plotted against these ratios obtained during the infusion of 1-norepinephrine. The hemoglobin clearance increased relative to the creatinine clearance in all studies but one.

of hemoglobin, which elicits intrarenal vasoconstriction (16). The mean glomerular filtration rate was $41 \mathrm{ml}$. per $10 \mathrm{~kg}$. body weight per minute, a figure not significantly different from normal values (15).

During infusion of 1-norepinephrine renal plasma flow (RPF, Table I) decreased in all dogs but one (dog 25). The mean renal plasma flow at this time was 63 per cent of control values, with a range of 16 to 96 per cent of control levels. Glomerular filtration rate (GFR, Table I) diminished more than 10 per cent in 17 dogs (range of 
change, 11 to 70 per cent), remained unchanged in two (dogs 25 and 31 ) and increased in one (dog 10). For the entire group the mean value of GFR during the infusion of 1-norepinephrine was 71 per cent of control levels. There was no correlation between the magnitude of blood pressure elevation and the degree of change in GFR. The correlation between the rate of infusion of 1-norepinephrine and the change in GFR was significant $(r=-$ $.446 ; \mathrm{p}<.05>.01)$. The filtration fraction (FF, Table I) increased in 11 dogs, decreased in 4 and remained unchanged in 5 . On cessation of infusion of 1-norepinephrine RPF, GFR, and FF returned towards control values (recovery period, Table I).

Urinary hemoglobin excretion ( $U_{H g b} V$, Table I, Figure 1) increased during the pressor response to 1 -norepinephrine in 17 studies, decreased in 2 (dogs 9 and 11) and remained unchanged in one (dog 25). The mean excretory rate at this time was 166 per cent of control values with a range of 81 to 316 per cent. These changes in excretion were usually but not invariably accompanied by an increase in the concentration of hemoglobin in plasma. In 17 animals the plasma level of hemoglobin increased 10 to 40 per cent (mean change, 20 per cent); in three (dogs 8,9 and 25 ) the plasma level did not change. The rise in plasma concentration may be attributed to the hemocon-

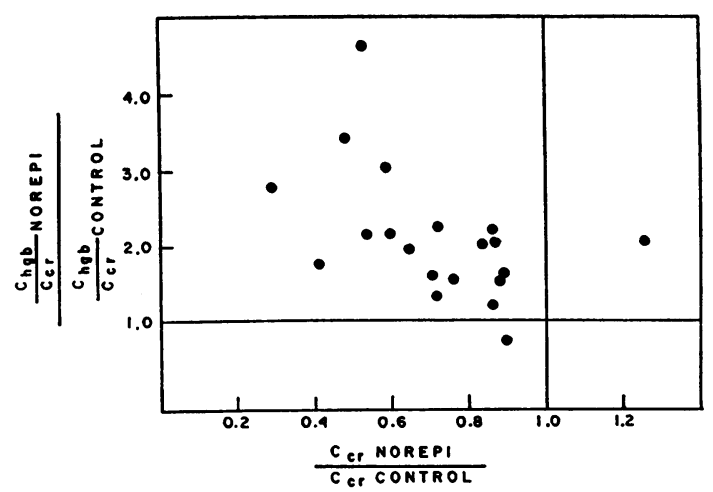

Fig. 5. The Relationship Between the Clearance of Creatinine and the Hemoglobin-Creatinine Clearance Ratio During the Pressor Response to L-NorEPINEPHRINE

The ratio of the infusion to the control values of the hemoglobin-creatinine clearance ratios $\left(\mathrm{C}_{\mathrm{Hgb}} / \mathrm{C}_{\mathbf{C r}}\right)$ is plotted against the ratio of the infusion to control values of the clearance of creatinine $\left(\mathrm{C}_{\mathrm{Cr}_{r}}\right)$. As $\mathrm{C}_{\mathrm{C}_{r}}$ diminished, the clearance of hemoglobin increased relative to creatinine. In one study $\mathrm{C}_{\mathrm{Eg}} / \mathrm{C}_{\mathrm{Cr}}$ increased as $\mathrm{C}_{\mathrm{Cr}}$ rose.

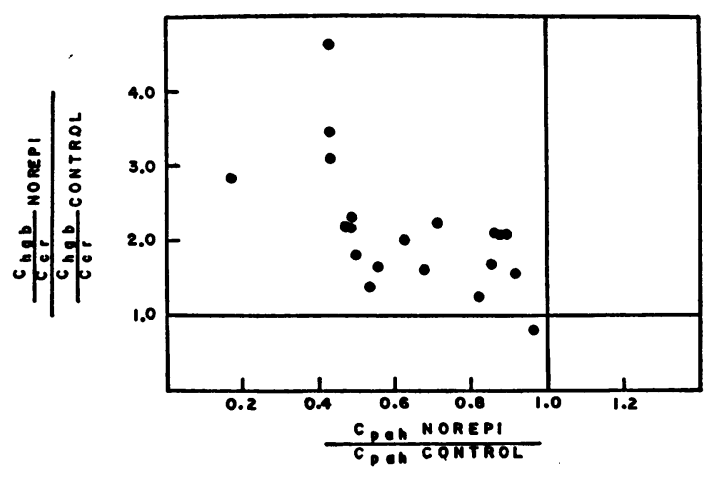

Fig. 6. The Relationship Between the Clearance of PAH and the Hemoglobin-Creatinine Clearance Ratio During the Pressor Response to L-NorepiNEPHRINE

The ratio of the infusion to the control values of the hemoglobin-creatinine clearance ratios $\left(\mathrm{C}_{\mathbf{B g b}} / \mathrm{C}_{\mathbf{c r}}\right)$ is plotted against the ratio of the infusion to the control values of the PAH clearance. As the clearance of PAH diminished, the clearance of hemoglobin increased relative to creatinine.

centrating effects of 1-norepinephrine $(17,18)$ and, in some instances, to a greater rate of administration than of excretion of hemoglobin.

The renal clearance of hemoglobin $\left(\mathrm{C}_{\mathrm{Hg}}\right.$, Table I) showed similar directional changes (Figure 2). However, since the concentration of hemoglobin in plasma increased in most studies, the percentage change in hemoglobin clearance was less than that of hemoglobin excretion. $\mathrm{C}_{\mathrm{Hgb}}$ increased in 14 animals, decreased in 4 (dogs 9,11 , 19 and 25) and remained unchanged in 2 (dogs 14 and 16). This variability may be attributed in part to the magnitude of the reduction in the volume of glomerular filtrate, since the clearance of hemoglobin tended to fall when GFR was reduced more than 50 per cent (Figure 3 ). The mean $\mathrm{C}_{\mathbf{H g b}}$ during the infusion of 1-norepinephrine was 137 per cent of control values with a range of 69 to 267 per cent.

On cessation of the infusion, the excretion and clearance of hemoglobin returned towards control values in three studies (dogs 33,34 and 35) and increased in three (dogs 17,18 and 25). The increase in $\operatorname{dog} 25$ was spurious since this animal developed gross hematuria during the recovery periods.

The hemoglobin-creatinine clearance ratio $\left(\mathrm{C}_{\mathbf{H g b}}\right.$ $/ \mathrm{C}_{\mathrm{Cr}}$, Table I) increased in every study but one (dog 25) (Figure 4). The mean value during the 
administration of 1-norepinephrine was 211 per cent of control levels with a range of 75 to 463 per cent. The correlation between the changes in this ratio and GFR was of borderline significance $(r=-0.436 ; p<.10>.05)$ (Figure 5). ${ }^{5}$ The correlation between the changes in $\mathrm{C}_{\mathrm{Hgb}} / \mathrm{C}_{\mathrm{Or}}$ and $\mathrm{RPF}$ was significant $(\mathrm{r}=-0.590 ; \mathrm{p}<.01)$ (Figure 6). On cessation of the infusion of 1-norepinephrine the hemoglobin-creatinine clearance ratio returned towards control levels in all animals except $\operatorname{dog} 25$, which developed gross hematuria.

\section{DISCUSSION}

Hemoglobin molecules circulating in plasma are excreted in the urine at a rate which is determined by the rate of transport of these molecules across the glomerular membrane and by the capacity of the renal tubular cells to abstract this protein from glomerular filtrate during the process of urine formation. The present study suggests that either one or both of these processes concerned in hemoglobin excretion may be modified during the pressor response to 1-norepinephrine. The increase in urinary excretion and in the renal clearance of hemoglobin elicited by the infusion of 1-norepinephrine may be attributed to either an increase in transglomerular transport of hemoglobin or to a decrease in tubular reabsorption, or to both. Although the precise mechanism of this excretory response was not established, the magnitude of the changes suggests that alterations in tubular reabsorption alone were not responsible. In dogs 12 , 13 , and 33 the increment in hemoglobin excretion exceeded $2.0 \mathrm{mgm}$. per minute (by 2.2, 4.62, and $2.83 \mathrm{mgm}$. per minute, respectively), the approximate maximal rate of tubular reabsorption of hemoglobin in dogs the size of those employed in the present study (10). Hence, the augmented hemoglobin excretion may be attributed, at least in part, to a more rapid rate of transfer of hemoglobin molecules into glomerular filtrate. Whether changes in tubular reabsorption also occurred is not known.

The mechanism of this alteration in transglomerular transport is not clear. Since the concen-

${ }^{5}$ When the one study ( $\left.\operatorname{dog} 10\right)$ in which the creatinine clearance increased is omitted from these calculations, the correlation between GFR and $\mathrm{C}_{\mathrm{Hgb}} / \mathrm{C}_{\mathrm{Or}_{\mathrm{r}}}$ is significant $(\mathrm{r}=-0.539 ; \mathrm{p}<.02>.01)$. tration of hemoglobin in glomerular filtrate rises in a linear manner as plasma hemoglobin concentration increases $(10,19)$, the increment in plasma concentration usually elicited in the present study by the infusion of 1 -norepinephrine undoubtedly contributed to this increase in transport in most studies. However, the increase in plasma level was inconstant (dogs 8 and 9) and was insufficient in most instances to account for the magnitude of the increment in the clearance of hemoglobin and in the hemoglobin-creatinine clearance ratio. ${ }^{\circ}$ Hence other factors appear to have been operative as well to augment the glomerular transport of this protein.

That alterations in glomerular filtration rate may have initiated these changes in transport must

- This view can be illustrated by theoretical calculations of the change in the clearance of hemoglobin and in the hemoglobin-creatinine clearance ratio to be expected by a 20 per cent increase in the plasma hemoglobin concentration, the average increment observed in the present study during the infusion of l-norepinephrine.

(a) Assuming the following values: plasma hemoglobin concentration, $3.0 \mathrm{mgm}$. per $\mathrm{ml}$.; creatinine clearance, 40 ml. per minute; glomerular permeability to hemoglobin, 5 per cent of the creatinine clearance $(18)$; and $\mathrm{T}_{\mathbf{M}_{\mathbf{B g}}}$, $2.0 \mathrm{mgm}$. per minute :

$$
\begin{aligned}
& \begin{array}{l}
\text { Filtered } \mathrm{Hgb}=3.0 \times 40 \times .05 \\
=6.00 \mathrm{mgm} . / \mathrm{min} .
\end{array} \\
& \begin{array}{ll}
\text { Reabsorbed } \mathrm{Hgb} & =2.00 \mathrm{mgm} . / \mathrm{min} . \\
\text { Excreted } \mathrm{Hgb} & =4.00 \mathrm{mgm} . / \mathrm{min} . \\
\mathrm{C}_{\mathrm{Bgb}} & =\frac{4.00}{3.00}=1.33 \mathrm{ml} . / \mathrm{min} . \\
\mathrm{C}_{\mathrm{Bgb}} / \mathrm{C}_{\mathrm{Cr}} & =\frac{1.33}{40}=.033
\end{array}
\end{aligned}
$$

(b) Assuming a 20 per cent increase in $P_{H_{g b}}$ and no change in glomerular permeability or tubular reabsorption:

$$
\begin{aligned}
& \text { Filtered } \mathrm{H}_{\mathrm{gb}}=(3.0+0.6) \times 40 \times .05 \\
& =7.20 \mathrm{mgm} . / \mathrm{min} \text {. } \\
& \text { Reabsorbed } \mathrm{H}_{\mathrm{gb}}=2.00 \mathrm{mgm} . / \mathrm{min} \text {. } \\
& \text { Excreted } \mathrm{H}_{\mathrm{gb}} \quad=5.20 \mathrm{mgm} . / \mathrm{min} \text {. } \\
& \mathrm{C}_{\mathrm{H}_{\mathrm{g}} \mathrm{b}} \quad=\frac{5.20}{3.60}=1.44 \mathrm{ml} . / \mathrm{min} \text {. } \\
& \mathrm{C}_{\mathrm{Bg}} \mathrm{b} / \mathrm{C}_{\mathrm{Cr}} \quad=\frac{1.44}{40}=0.36
\end{aligned}
$$

These changes are less than those determined experimentally (average experimental change in $\mathrm{C}_{\mathrm{Ecb}}, 37$ per cent and in $\mathrm{C}_{\mathrm{E} g b} / \mathrm{C}_{\mathrm{Cr}}, 111$ per cent). Hence an increase in plasma hemoglobin concentration of 20 per cent cannot alone account for the observed alterations. 
be considered in view of the relationship between protein transport and filtration rate as formulated in the theory of molecular sieving. According to this theory, the concentration of protein in capillary filtrates increases as the rate of formation of filtrate diminishes, owing to differences in the diffusion characteristics of protein and water (creatinine) molecules (2-4). Although GFR characteristically fell in the present study, the role of this reduction is obscure. That the excretory response to 1-norepinephrine may have been modified by changes in GFR is evident in Figure 3, which shows that the typical increase in hemoglobin clearance was abolished by marked decrements of GFR. ${ }^{7}$ But whether adjustments of GFR initiated the excretory response to 1-norepinephrine in accordance with the concept of molecular sieving is not clear. In one study ( $\operatorname{dog} 10)$ the clearance of hemoglobin increased (both in absolute terms and relative to creatinine) in association with an increase rather than a decrease in GFR. Moreover, the relationship between filtration rate and protein transport is uncertain owing to doubt concerning the mechanism of the reduction of GFR in the dog during the vasoconstrictive response to 1 -norepinephrine. If, as has been suggested (20), filtration diminishes as a result of selective cessation of glomerular activity in a portion of the nephron population, the theory of molecular sieving as outlined cannot account for the changes in hemoglobin clearance elicited in the present study. Since, under these circumstances, filtration would be unaltered in those nephrons contributing to urine formation, the relationship between the transglomerular transport of hemoglobin and creatinine would not change in these nephrons and the hemoglobin-creatinine clearance ratio would remain constant. If, however, GFR decreases by a generalized, partial reduction of filtration in active nephrons, or if variable alterations of filtration rate in residual, active glomeruli occur during nephron exclusion, the transport of hemoglobin across the glomerular membrane of functioning

\footnotetext{
7 The decrease in the clearance of hemoglobin under these circumstances may be attributed to the marked reduction in the volume of glomerular filtrate. Since the clearance of hemoglobin increased relative to creatinine in these instances, the factors tending to augment the transglomerular transfer of hemoglobin appear to have been operative in these as in the other studies.
}

nephrons might increase relative to creatinine in accordance with the theory of molecular sieving and the clearance of hemoglobin would rise relative to creatinine. Until, however, the precise mechanism of the reduction of GFR is established, the role of these changes in filtration rate cannot be evaluated.

Studies of the effects of plasma volume expansion on proteinuria (5) and of the effect of renin on the excretion of hemoglobin and plasma proteins in rabbits and rats (7-9) have suggested that the transport of protein molecules across the glomerular membrane may be conditioned by the level of intracapillary hydrostatic pressure. Renin, which has hemodynamic effects in the kidney similar to those elicited by l-norepinephrine, is thought to elevate intraglomerular pressure by vasomotor adjustments of the efferent and afferent arterioles (8). This rise in pressure, it has been suggested (8), accelerates the filtration and/or diffusion of protein across the glomerular membrane by mechanisms which are not clear, but which may be related to stretching of the glomerular membrane (5). Whether 1-norepinephrine acts in a similar manner is not known. A rise in intraglomerular pressure would be expected to elevate glomerular filtration rate relative to renal plasma flow (an increase in the renal filtration fraction), a functional pattern which is elicited by both renin and 1-norepinephrine. But whether this relationship between filtration rate and plasma flow actually reflects adjustments of intraglomerular pressure is not clear (15). Moreover, if nephron exclusion occurs during the administration of 1-norepinephrine, a variable and uncertain relation between flow and filtration may exist in active and inactive nephrons and hemodynamic interpretation of the filtration fraction would be impossible. Hence the changes in protein transport elicited in the present study cannot be evaluated in terms of adjustments of intraglomerular pressure. Whether the level of hydrostatic pressure genuinely influences protein transport has not been unequivocally established. The precise role of this factor in the kidney and other sites remains to be determined.

That hemodynamic adjustments within the kidney may have altered the transport of hemoglobin across the glomerular membrane independently of alterations in glomerular filtration rate and intraglomerular pressure is possible. The relationship 
illustrated in Figure 6 indicates that as renal plasma flow diminished the clearance of hemoglobin increased relative to creatinine. Whether this correlation indicates a causal relationship between renal plasma flow and transglomerular hemoglobin transport is, however, not clearly established. Moreover, the mechanism by which changes in renal plasma flow might condition hemoglobin transport is obscure. An increased rate of transglomerular transport might occur under these conditions as a result of a reduction in the rate and velocity of blood flow through the glomerulus. If these changes in glomerular blood flow accompany a reduction in renal blood flow, the contact between hemoglobin molecules and the glomerular capillary wall may be prolonged, thus allowing more time for the diffusion of these molecules into glomerular filtrate.

This view may explain in part the relatively high values recorded for the glomerular permeability to hemoglobin in both man and dog, since the administration of this protein intravenously is attended by intrarenal vasoconstriction and a reduction of renal blood flow (16). Moreover, the higher values for glomerular permeability elicited when the rate of intravenous administration is increased (19) may be attributable to a greater reduction of blood flow through, and an increased rate of diffusion of hemoglobin from, the glomerulus under these conditions.

\section{SUMMARY}

The administration of pressor doses of 1-norepinephrine to anesthetized dogs elicited abrupt alterations in the urinary excretion and renal clearance of hemoglobin. When renal vasoconstriction was moderate, the clearance of hemoglobin increased; when renal vasoconstriction was intense and glomerular filtration rate diminished sharply, hemoglobin clearance decreased or remained unchanged, presumably since less filtrate was available for excretion under these conditions. Since the clearance of hemoglobin increased relative to filtration in all studies but one, regardless of the intensity of the vasoconstrictive adjustments, and since this change could not be attributed to a decrease in tubular reabsorption of hemoglobin alone, the administration of 1-norepinephrine apparently elicited an acceleration in the transglomerular capillary transport of hemoglobin molecules.

The mechanism of this change in transport was not determined. An increase in plasma hemoglobin concentration usually occurred and contributed to, but was not alone responsible for, the increase in transglomerular hemoglobin transport. The possibility that alterations in renal blood flow played a role was considered. The way in which a reduction in flow might have acted was not established, but it was suggested that if the rate and velocity of glomerular blood flow diminished as renal blood flow decreased, the contact between hemoglobin molecules and the glomerular membrane may have been prolonged, thus allowing more time for the diffusion of those molecules into glomerular filtrate. Although adjustments of glomerular filtration rate and intraglomerular hydrostatic pressure may have contributed to the observed changes in hemoglobin transport, the role of these adjustments could not be evaluated in the present study.

\section{ACKNOWLEDGMENT}

The authors are indebted to Miss Janet Webster and Miss Carolyn Patton for clinical assistance.

\section{REFERENCES}

1. Lathem, W., and Benjamin, A. D., Intrarenal circulatory dynamics and glomerular permeability to hemoglobin in dogs. J. Clin. Invest., 1956, 35, 719.

2. Pappenheimer, J. R., Renkin, E. M., and Borrero, L. M., Filtration, diffusion and molecular sieving through peripheral capillary membranes. A contribution to the pore theory of capillary permeability. Am. J. Physiol., 1951, 167, 13.

3. Pappenheimer, J. R., The passage of substances across capillary walls in Renal Function, Transactions of the Third Conference, Stanley E. Bradley, Ed., New York, Josiah Macy, Jr. Foundation, 1951, p. 12.

4. Renkin, E. M., Filtration, diffusion, and molecular sieving through porous cellulose membranes. J. Gen. Physiol., 1954, 38, 225.

5. Chinard, F. P., Lauson, H. D., Eder, H. A., Greif, R. L., and Hiller, A., A study of the mechanism of proteinuria in patients with the nephrotic syndrome. J. Clin. Invest., 1954, 33, 621.

6. Davson, H., and Danielli, J. F., The Permeability of Natural Membranes, Cambridge, England, Cambridge University Press, 1943. 
7. Pickering, G. W., and Prinzmetal, M., The effect of renin on urine formation. J. Physiol., 1940, 98, 314.

8. Addis, T., Barrett, E., Boyd, R. I., and Ureen, H. J., Renin proteinuria in the rat. $I$. The relation between the proteinuria and the pressor effect of renin. J. Exper. Med., 1949, 89, 131.

9. Lippman, R. W., Ureen, H. J., and Oliver, J., Mechanism of proteinuria. IV. Effect of renin on hemoglobin excretion. J. Exper. Med., 1951, 93, 605.

10. Monke, J. V., and Yuile, C. L., The renal clearance of hemoglobin in the dog. J. Exper. Med., 1940, 72, 149.

11. Evelyn, K. A., and Malloy, H. T., Microdetermination of oxyhemoglobin, methemoglobin and sulfhemoglobin in a single sample of blood. J. Biol. Chem., 1938, 126, 655.

12. Bonsnes, R. W., and Taussky, H. H., On the colorimetric determination of creatinine by the Jaffe reaction. J. Biol. Chem., 1945, 158, 581.

13. Smith, H. W., Finkelstein, N., Aliminosa, L., Crawford, B., and Graber, M., The renal clearances of substituted hippuric acid derivatives and other aromatic acids in dog and man. J. Clin. Invest., 1945, 24, 388.
14. Amberson, W. R., Jacobs, J. E., Hisey, A., and Monke, J. V., Hemoglobin-saline solutions as transfusion media in Blood Substitutes and Blood Transfusion, Mudd, S., and Thalheimer, W., Eds., Springfield, Ill., Charles C Thomas, 1942, p. 156.

15. Smith, H. W., The Kidney: Structure and Function in Health and Disease, New York, Oxford University Press, 1951.

16. Miller, J. H., and McDonald, R. K., The effect of hemoglobin on renal function in the human. $\mathrm{J}$. Clin. Invest., 1951, 30, 1033.

17. Edmunds, C. W., and Wilson, E. E., Factors concerned in the polycythemia produced by the subcutaneous injection of epinephrine. J. Exper. Med., 1925, 41, 1.

18. Lathem, W., Unpublished observations.

19. McDonald, R. K., Miller, J. H., and Roach, E. B., Human glomerular permeability and tubular recovery values for hemoglobin. J. Clin. Invest., 1951, 30, 1041.

20. Moyer, J. H., and Handley; C. A., Norepinephrine and epinephrine effect on renal hemodynamics with particular reference to the possibility of vascular shunting and decreasing the active glomeruli. Circulation, 1952, 5, 91. 